Vol.59: e16150585, January-December 2016 http://dx.doi.org/10.1590/1678-4324-2016150585

ISSN 1678-4324 Online Edition
BRAZILIAN ARCHIVES OF BIOLOGY AND TECHNOLOGY

AN INTERNATIONAL JOURNAL

\title{
Comparison of therapeutic effects of L-Thyroxin, apelin and a combination of both on antioxidant enzymes in the heart of PTU-induced hypothyroid rats
}

\author{
Farzaneh Faraji Shahrivar ${ }^{1}$, Mohammad Badavi ${ }^{1 *}$, Mahin Dianat ${ }^{1}$, Ali Mard ${ }^{2}$, Akram \\ Ahangarpour ${ }^{1}$, Mehdi Hedayati ${ }^{3}$ and Alireza Samarbaf-zadeh ${ }^{4}$ \\ ${ }^{1}$ Physiology Research Center, Department of Physiology, Faculty of Medicine, Ahvaz Jundishapur University of \\ Medical Sciences, Ahvaz, Iran. ${ }^{2}$ Physiology Research Center, Research Center for Infectious Diseases of Digestive \\ System and Department of Physiology, Faculty of Medicine, Ahvaz Jundishapur University of Medical Sciences, \\ Ahvaz, Iran. ${ }^{3}$ Cellular and Molecular Endocrine Research Center, Research Institute for Endocrine Sciences, \\ ShahidBeheshti University of Medical Sciences, Tehran, I. R. Iran. ${ }^{4}$ Health Research Institute, Infectious and \\ Tropical Diseases Research Center, Department of Virology, Ahvaz Jundishapur University of Medical Sciences, \\ Ahvaz, Iran
}

\begin{abstract}
Atherosclerosis is one of the common disorders among hypothyroidism, which, increased the risk of cardiovascular diseases. Reactive oxygen species are associated with atherosclerosis development. Antioxidant defense systems are the scavenger for free radicals. Apelin is an endogenous ligand for the APJ receptor (apelin receptor) that exists in most tissues, acts as an adiponectin. It has been identified that apelin administration, improve the antioxidant capacity (TAC). Therefore, this study was conducted to assess, therapeutic effects of apelin, T4 (L-Thyroxin) or both on antioxidant capacity in 6-propyl-2-thiouracil (PTU)-induced hypothyroid rats. Forty male Wistar rats were randomly assigned into five groups: C: control group; P group (hypothyroid): PTU (0.05\%) administration for six weeks; P+A, P+T and P+A+T groups: after 4 weeks of PTU administration, animals treated with Apelin (200 $\mu \mathrm{g} / \mathrm{kg} / \mathrm{day}$, ip) T4 $(0.02 \mu \mathrm{g} / \mathrm{g} /$ day, gavage $)$ and apelin $+\mathrm{T} 4$; for two weeks respectively accompanied by PTU administration. Aplein administration in $P+A$ group and $P+A+T$ group had beneficial effect to lowering of malondialdehyde (MDA) content as compared to hypothyroid group $(8.52 \pm 0.64$ and $8.53 \pm 1 \mathrm{vs.} 13.67 \pm 1.64 \mathrm{nmol} / \mathrm{g}$ tissue, $P<0.05)$ and also had increasing effect on Superoxide dismutase (SOD) and glutathion peroxidase (GPX) activity and the total antioxidant capacity (TAC) content compared to the hypothyroid group. This study showed that apelin was able to improve the oxidant-antioxidant balance in the heart tissue of the hypothyroid rats by elevating of antioxidant enzyme activity.
\end{abstract}

Key words: Apelin, Antioxidative, Hypothyroid, Rat, Thyroxin

\footnotetext{
*Corresponding Author: badavim@yahoo.com
} 


\section{INTRODUCTION}

Hypothyroidism is associated with the increased risk for atherosclerosis and ischemic heart diseases (Cappola and Ladenson 2003). Several studies have shown that reactive oxygen species (ROS) are involved in the process of atherosclerosis (Mishra and Samanta 2012). The available, finding concerning oxidant stress and antioxidant capacity in hypothyroidism is scantly and controversial. Some studies report that tissues may be protected from oxidant damage because of a hypometabolic state in hypothyroidism (Pereira et al. 1994). Whereas some other studies suggest that oxidative stress is increased in hypothyroidism and oxidize low density lipoprotein cholesterol (LDL-C) and finally prone to atherosclerosis (Sundaram et al. 1997). Moreover, there is some controversial finding about the content and activity of enzymatic antioxidant in hypothyroidism; the studies showed that the increase or decrease or unchanged of SOD, catalase and glutathion peroxidase in hypothyroid patients (Das and Chainy 2001; Messarah et al. 2007; Araujo et al. 2011). To our knowledge, there is not any study demonstrating the effects of thyroid hormone replacement therapy by apelin and $\mathrm{T} 4$ or a combination of both on enzymatic antioxidant activity.

Apelin is an endogenous peptide that expressed in various tissues including adipose tissue, heart, vessels, lung, testis, ovary, mammary glands, brain, liver, skeletal muscle and kidney, as well as acts as a ligand for the APJ receptor (APJ; gene symbol of apelin receptor, $G$ proteincoupled receptor) (Kawamata et al. 2001; Tatemoto et al. 2001). It is a powerful inotrope, peripheral vasodilator, and may affect central fluid homeostasis, energy storage and metabolism (Chandrasekaran et al. 2008). Apelin is also considered as an adipokine, in adipose tissue (Boucher J1 2005). It has been reported that synthesis and secretion of adipokines, and other inflammatory mediators are involved in the atherosclerotic progress (von Eynatten et al. 2006).
Some studies reported that apelin increase mRNA expression and activity of SOD, catalase and glutathion peroxidase and decreased MDA (it is the end stage of the lipid peroxidation process and identify for lipid peroxidation evaluation) in cardiac cell and tissue (Aikawa et al. 2001; Foussal et al. 2010). An absence of thyroid hormones causes morphological and structural changes in cardiac myocytes that brings about changes in hemodynamic characteristics which hypothyroid patient suffering from them (Fazio et al. 2004; Klein and Danzi 2007). The oxidant-antioxidant imbalance is one of the reasons in pathogenesis of tissue damage (Halliwell1994). On the other hand, the atherosclerosis in coroner, increase the rate of myocardial infarction (Jashari et al. 2013). Therefore the present study was designed to investigate the therapeutic effects of apelin, T4 or a combination of both on antioxidant capacity and the lipid peroxidation in the heart of PTUinduced hypothyroid rats.

\section{MATERIALS AND METHODS}

\begin{abstract}
Materials
Ketamine and Xylazine were purchased from Alfasan Co. (Holland). 6-propyl-2-thiouracil (PTU) and L-Thyroxin (T4) were obtained from Sigma-Aldrich Co. (USA). Apelin was purchased from Cayman Chemical Co. (USA). 6-propyl-2thiouracil (PTU) $(0.05 \%)$ was dissolved in tap water; Apelin $(200 \mu \mathrm{g} / \mathrm{kg})$ was dissolved in normal saline and was injected intraperitoneally. L-Thyroxin was dissolved in 0.1 normal $\mathrm{NaOH}$, and then was diluted with tap water to the desired concentration $(0.02 \mu \mathrm{g} / \mathrm{g})$ and was gavaged.
\end{abstract}

\footnotetext{
Animal treatment and sample collection

Forty male Wistar rats (190-230 g) were obtained from the animal house of the Ahvaz Jundishapur University of Medical Sciences and housed in standard conditions $\left(22 \pm 2^{\circ} \mathrm{C}\right.$ with a $12 / 12 \mathrm{~h}$ light-dark cycle). The animals had free access to standard rat chow diet (Pars Co., Iran) and tap water. All procedures were approved by the ethical committee of the Ahvaz Jundishapur University of Medical Sciences (APRC 148,
} 
2013/03/07) and performed in accordance with appropriate standards for animal use and care.

Rats were randomly assigned into five groups ( $\mathrm{n}=8$ each): Control (C), $\mathrm{P}$ (Hypothyroid), $\mathrm{P}+\mathrm{A}$, $\mathrm{P}+\mathrm{T}$, and $\mathrm{P}+\mathrm{A}+\mathrm{T}$ groups. All groups received $0.05 \%$ 6-propyl-2-thiouracil (PTU) in the drinking water (Pan et al. 2013) for six weeks, except the control group that received vehicle; normal saline, ip injection and tab water gavage. The $\mathrm{P}+\mathrm{A}, \mathrm{P}+\mathrm{T}$, and $\mathrm{P}+\mathrm{A}+\mathrm{T}$ groups received; apelin $(200 \mu \mathrm{g} / \mathrm{kg} /$ day, ip)(Falcao-Pires and Leite-Moreira 2005), T4 (0.02 $\mu \mathrm{g} / \mathrm{g} / \mathrm{day}$, gavage)(Pan et al. 2013), and apelin (200 $\mu \mathrm{g} / \mathrm{kg} /$ day, ip) accompanied by T4 (0.02 $\mu \mathrm{g} / \mathrm{g} /$ day, gavage) in the last two weeks, respectively.

Body weight of rats was recorded weekly. At the end of the experiment, $12 \mathrm{~h}$ fasted rats were killed by an overdose of anesthetic drug, abdomen was opened and then exsanguinated from the abdominal aorta, Then, serum was separated from the blood and immediately frozen at -20 $\square \mathrm{C}$ until assayed. Serum levels of Thyroxin (T4) and thyroid stimulating hormone (TSH) were assayed using ELISA kits from DiaPlus (USA) and TSH ELISA kits from the Cusabio Company (China), respectively.

\section{Tissue Preparation}

$100 \mathrm{mg}$ of the left ventricular tissues homogenized in $1 \mathrm{ml}$ phosphate buffer $(0.1 \mathrm{M}$, $\mathrm{PH}=7.4)$ on cold place. Homogenates were centrifuged for $10 \mathrm{~min}$ at $4 \square \mathrm{C}$, and supernatants were stored at $-20 \square \mathrm{C}$ until assayed the activity of antioxidant enzymes and content of MDA and TAC.

\section{Determination of lipid peroxidation}

Malondialdehyde (MDA) was determined by the thiobarbituric acid method, using ELISA kit from
Bioassay System (USA), according to manufacturer's instructions.

\section{Determination of antioxidant enzyme activity}

The activity of SOD, catalase, glutathion peroxidase enzymes, and total antioxidant capacity (TAC) content was assayed by using ELISA kit form Bioassay System (USA), according to manufacturer's instructions.

\section{Determination of protein concentration}

Total protein concentration was measured by Bradford's method, using bovine serum albumin as the standard (Jahanbakhsh et al. 2012).

\section{Statistical analysis}

Statistical analysis was performed with SPSS 20, and data expressed as mean \pm standard error of mean (SEM). Comparisons were made by oneway analyses of variance (ANOVA) followed by the LSD test. $\mathrm{P}$ value $<0.05$ was considered as statistically significant.

\section{RESULTS}

\section{Serum TSH and T4 levels}

In hypothyroid rats, compared to the control group, Serum level of TSH was significantly increased $(\mathrm{P}<0.01$, Table 1$)$, whereas $\mathrm{T} 4$ was decreased $(\mathrm{P}<0.01)$, values indicating successful induction of hypothyroidism by PTU. Compared to the control group, In $\mathrm{P}+\mathrm{A}$ and $\mathrm{P}+\mathrm{A}+\mathrm{T}$ groups, serum level of $\mathrm{T} 4$ was significantly lower after 14 days of treatment, while those of serum TSH were significantly higher $(\mathrm{P}<0.05)$. In $\mathrm{P}+\mathrm{T}$ group, serum level of $\mathrm{T} 4$ had not significant difference compared to the control group, but the TSH levels were significantly higher $(\mathrm{P}<0.05)$.

Table 1 - Serum levels of TSH and T4 in different groups (Mean \pm S.E.M., n=8)

\begin{tabular}{lccccc}
\hline Groups & $\mathbf{C}$ & $\mathbf{P}$ & $\mathbf{P}+\mathbf{A}$ & $\mathbf{P}+\mathbf{T}$ & $\mathbf{P}+\mathbf{A}+\mathbf{T}$ \\
\hline TSH $(\mathrm{mIU} / \mathrm{L})$ & $1.3 \pm 0.2$ & $17.5 \pm 2.8^{* *}$ & $14.1 \pm 2.4^{* *}$ & $17.1 \pm 2.1^{* *}$ & $9.6 \pm 1.8^{* *}$ \\
T4 $(\mathrm{nmol} / \mathrm{L})$ & $75.5 \pm 4.6$ & $18.3 \pm 2.3^{* *}$ & $13.3 \pm 1.6^{* * \dagger}$ & $87.1 \pm 8.3^{\dagger \dagger}$ & $40 \pm 3.4^{\dagger \dagger}$ \\
\hline
\end{tabular}

C: control group (normal saline injection and tab water gavage); P (Hypothyroid group): (0.05\% PTU in the drinking water for six weeks); $\mathrm{P}+\mathrm{A}, \mathrm{P}+\mathrm{T}, \mathrm{P}+\mathrm{A}+\mathrm{T}$ groups: after 4 weeks of PTU administration, animals treated with Apelin $(200 \mu \mathrm{g} / \mathrm{kg} /$ day, ip,), T4 $(0.02 \mu \mathrm{g} / \mathrm{g} /$ day, gavage), and apelin+T4; for two weeks respectively accompanied by PTU administration. ${ }^{*} \mathrm{P}<0.05$, and ${ }^{* *} \mathrm{P}<0.01$ compared to the control; ${ }^{\dagger} \mathrm{P}<0.05$, and ${ }^{\dagger} \mathrm{P}<0.01$ compared to the $\mathrm{P}$ group. The analysis of data was done by one-way ANOVA followed by LSD test. 


\section{MDA levels}

As compared to the control groups, MDA level was non-significantly increased in the $\mathrm{P}$ group $(13.67 \pm 1.64$ vs. $10.25 \pm 0.92 \mathrm{nmol} / \mathrm{g}$ tissue $)$ (Fig. 1).

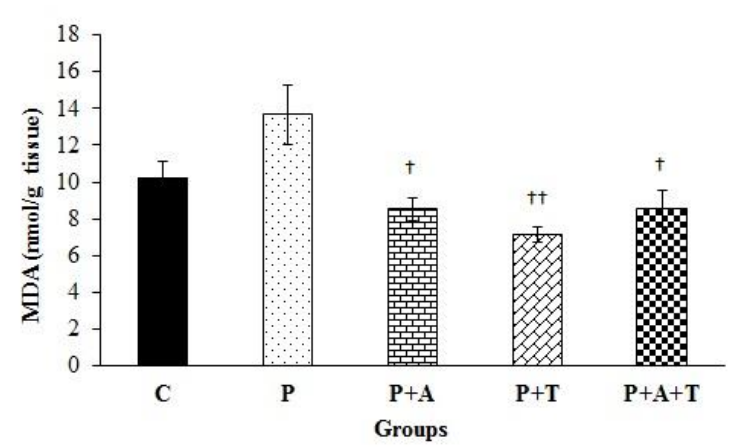

Figure 1 - Comparison of malondialdehyde (MDA) content in different groups. Data are expressed as mean \pm SEM, $n=8$. The $C$ : control group; $P$ (hypothyroid group): PTU administration for six weeks; $\mathrm{P}+\mathrm{A}, \mathrm{P}+\mathrm{T}, \mathrm{P}+\mathrm{A}+\mathrm{T}$ groups: after for 4 weeks of PTU administration, animals treated with Apelin (200 $\mu \mathrm{g} / \mathrm{kg} / \mathrm{day}, \mathrm{ip}), \mathrm{T} 4(0.02 \mu \mathrm{g} / \mathrm{g} / \mathrm{day}$, gavage) and apelin+T4; for two weeks respectively accompanied by PTU administration. $\uparrow \mathrm{P}<0.05 ; \dagger \uparrow \mathrm{P}<0.01$ compared to the $\mathrm{P}$ group. The analysis of data was done by oneway ANOVA followed by LSD test.

Administration of apelin or T4 separately in $\mathrm{P}+\mathrm{A}$ and $\mathrm{P}+\mathrm{T}$ groups, or a combination of both in $\mathrm{P}+\mathrm{A}+\mathrm{T}$ group decreased significantly MDA level in left ventricular tissue compared to $\mathrm{P}$ group $(8.52 \pm 0.64,7.11 \pm 0.41$ and $8.53 \pm 1$ vs. 13.67 $\pm 1.64 \mathrm{nmol} / \mathrm{g}$ tissue, $\mathrm{P}<0.05, \mathrm{P}<0.01, \mathrm{P}<0.05$ respectively).

\section{Total antioxidant capacity levels (TAC)}

Total antioxidant capacity in the $\mathrm{P}$ group was significantly decreased compared with the control group $(0.064 \pm 0.003$ vs. $0.125 \pm 0.011$ $\mathrm{U} / \mathrm{mg}$ tissue) (Fig. 2). As compared with the hypothyroid group, TAC was increased significantly in all treated groups, $(\mathrm{P}+\mathrm{A}: 0.1257$ $\pm 0.013, \mathrm{P}+\mathrm{T}: 0.117 \pm 0.007, \mathrm{P}+\mathrm{A}+\mathrm{T}: 0.011 \pm$ 0.007 vs. $0.064 \pm 0.003 \mathrm{U} / \mathrm{mg}$ tissue, $\mathrm{P}<0.01$ ).

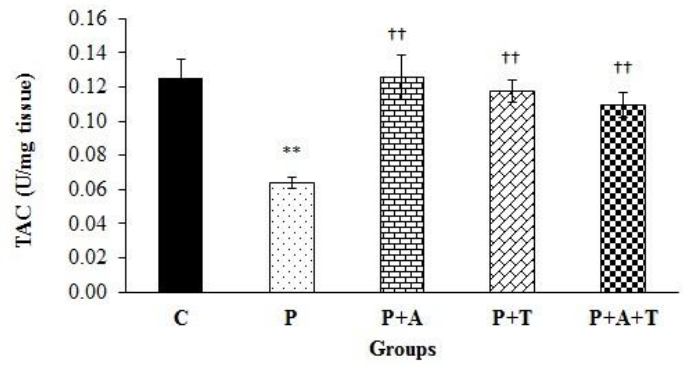

Figure 2 - Comparison of total antioxidant capacity (TAC) in different groups. Data are expressed as mean $\pm \mathrm{SEM}, \mathrm{n}=8 . * * \mathrm{P}<0.01$ compared to the control group, $\dagger \dagger \mathrm{P}<0.01$ compared to the $\mathrm{P}$ group. The analysis of data was done by one-way ANOVA followed by LSD test.

\section{SOD activity}

Figure 3 showed that, SOD was significantly decreased in the $\mathrm{P}$ group compared to the controls $(4.23 \pm 0.29$ vs. $6.17 \pm 0.44 \mathrm{U} / \mathrm{mg}$ protein, $\mathrm{P}<0.01$ ) (Fig. 3). Compared to the control and hypothyroid groups, administration of apelin and T4 alone or a combination of both could significantly increase the SOD activity in the $\mathrm{P}+\mathrm{A}, \mathrm{P}+\mathrm{T}$ and $\mathrm{P}+\mathrm{A}+\mathrm{T}$ groups, respectively $(7.33 \pm 0.62,8.06 \pm 0.44,8.5 \pm 0.44$ vs. $4.23 \pm$ $0.29 \mathrm{U} / \mathrm{mg}$ protein, $\mathrm{P}<0.01)$.

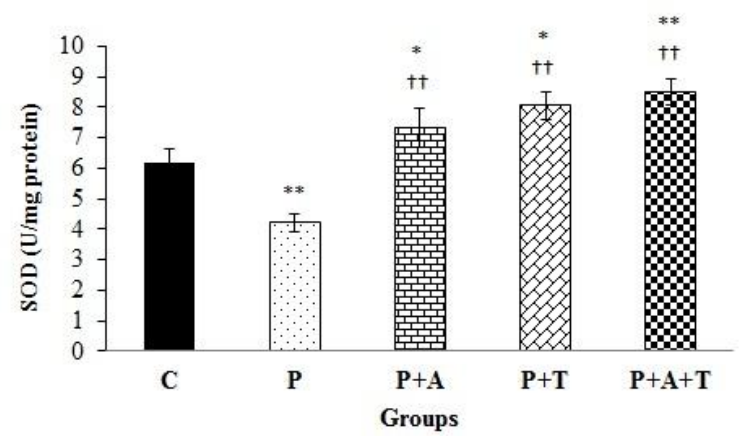

Figure 3- Comparison of superoxide dismutase (SOD) activity in different groups. Data are expressed as mean $\pm \mathrm{SEM}, \mathrm{n}=8 . * \mathrm{P}<0.05 ; * * \mathrm{P}<0.01$ compared to the control group, $\dagger \dagger \mathrm{P}<0.01$ compared to the $\mathrm{P}$ group. The analysis of data was done by one-way ANOVA followed by LSD test.

\section{Catalase activity}

There was observed a significant increasing in catalase activity in hypothyroid group compared to the control group $(4.19 \pm 0.22$ vs. $2.51 \pm 0.09$ U/mg protein, $\mathrm{P}<0.01$ ) (Fig. 4). 


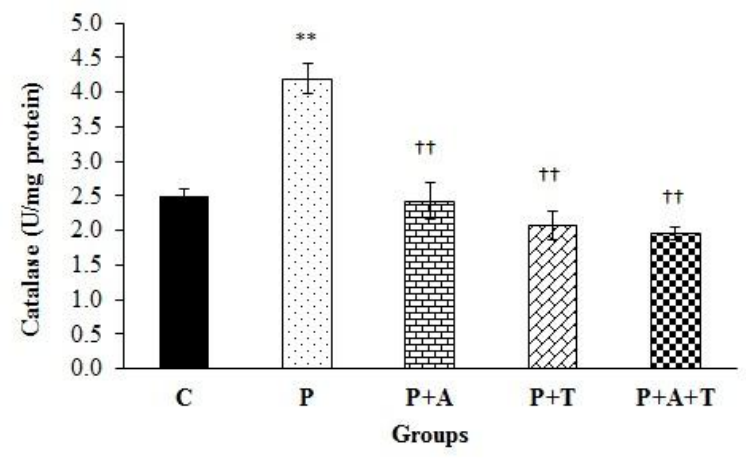

Figure 4 - Comparison of catalase activity in different groups.

Data are expressed as mean $\pm \mathrm{SEM}, \mathrm{n}=8$. $* * \mathrm{P}<0.01$ compared to the control group, $\uparrow \uparrow \mathrm{P}<0.01$ compared to the $\mathrm{P}$ group. The analysis of data was done by oneway ANOVA followed by LSD test.

It has no significant difference observed between all treated groups $(\mathrm{P}+\mathrm{A}, \mathrm{P}+\mathrm{T}, \mathrm{P}+\mathrm{A}+\mathrm{T})$ and control groups in catalase activity $(2.43 \pm 0.26$, $2.07 \pm 0.21,1.96 \pm 0.09$ vs. $2.51 \pm 0.09 \mathrm{U} / \mathrm{mg}$ protein, respectively).

\section{Glutathione peroxidase activity (GPx)}

There was no showed a significant change in the glutathione peroxidase activity between hypothyroid and control groups. Glutathione peroxidase activity increased in all treated groups compared with the hypothyroid group $(\mathrm{P}+\mathrm{A}$ : $68.59 \pm 2.14, \mathrm{P}<0.05, \mathrm{P}+\mathrm{T}: 69.02 \pm 2.7, \mathrm{P}+\mathrm{A}+\mathrm{T}$ : $71.82 \pm 3.1$ vs. $53.74 \pm 9.3 \mathrm{U} / \mathrm{mg}$ tissue, $\mathrm{P}<0.01$ )

\section{DISCUSSION}

This finding for the first time highlights to evaluate of the therapeutic effects of apelin and $\mathrm{T} 4$ or a combination of both on antioxidant capacity and lipid peroxidation in PTU-induced hypothyroid rats. The results of this study indicated that the therapeutic effect of apelin or T4 separately or a combination of both decreased MDA in hypothyroid rats after 14 days of treatment in cardiac tissue.

Findings about stress oxidative and activity of antioxidants in hypothyroidism are limited and controversial. There are some data that show in patients with hypothyroidism, oxidative stress, is increased (Lampka et al. 2006; Sarandol et al. 2005), decreased (Venditti et al. 1997) or remain unchanged (Coria et al. 2009). In agreement with the results of the current study, Reddy, et al. demonstrated that the serum level of MDA and GPx activity increase in hypothyroid and subclinical hypothyroid patients (Reddy et al. 2013). Another study showed that lipid peroxidation increase and an antioxidant level decrease in blood of hypothyroid patients (Dumitriu et al. 1988). Moreover, it has been demonstrated that the MDA content in plasma, liver and muscle of hypothyroid patients is increased (Yilmaz et al. 2003). Also, another finding has shown an increasing of lipid peroxidation in plasma, liver, heart, and muscle of PTU-induced hypothyroid rats. In contrast to the finding of this study, Pereira, et al. showed that lipid peroxidation is decreased in the rat lymphoid organ (Pereira et al. 1994).

However, it appears that the difference of finding of these studies may be due to the length of disease or experimental design or diffraction of tissue or animal species.

Atherosclerosis were observed in the long-term duration of hypothyroidism (Ichiki 2010), it has been demonstrated that the oxidative stress contribute to the formation of atherosclerosis (Mishra and Samanta 2012), therefore, decrease in lipid peroxidation and increasing in the antioxidant capacity lead to prevent of atherosclerosis formation.

This study showed that administration of apelin could reduce the MDA levels in heart tissue of PTU-induced hypothyroid rats. In agreement with the results of this study, Pisarenko, et al. has reported that apelin administered five minutes before induction of ischemia of heart could lower the level of MDA in heart tissue (Pisarenko et al. 2014). Another study reported that the chronic administration of apelin-13 decreased the lipid hydroperoxide in the plasma of rats (Foussal et al. 2010).

Apelin stimulates gene expression and activity of eNOS and finally due to nitric oxide (NO) generation (Japp et al. 2008). NO prevent of oxygen disruption in mitochondria and also lipid peroxidation (O'Donnell et al. 1997). On the other hand, it has been reported that in hypothyroidism the expression of NOS increase age dependently (Sarati et al. 2012). Moreover a study showed that after PTU administration, 
eNOS content is increased in the rat aorta (Grieve et al. 1999). It appeared that apelin and PTU potentiate their effect on eNOS activity, after14 days of treatment, and decrease the MDA level that is a criteria for lipid peroxidation.

The finding of this study showed a significant decreasing in antioxidant enzyme activity, except catalase activity, which raised, and total antioxidant capacity in $\mathrm{P}$ groups compared to the control group. There is some contradictory finding about antioxidant capacity and hypothyroidism. Das, et al. reported that the activity of SOD and catalase reduce in the liver of PTU-induced hypothyroid rats (Das and Chainy 2001). In addition, it showed that T3 therapy can increase the catalase activity and decrease the SOD activity in PTU-induced hypothyroid rats (Das and Chainy 2001). Another study showed that SOD and catalase activity in the erythrocytes of thyroidectomized rats remains unchanged (Araujo et al. 2011). It has demonstrated that, some of anti-thyroid drugs such as PTU and methimazol have an antioxidant property; these drugs decrease the free radical generation in thyroid cell by reduction cytokine production (Hicks et al. 1992; Weetman et al. 1992). In this study, oxidative stress has not been measured. Moreover, it has been reported that in hypothyroidism, metabolism rate decreases. So, this may be one of the reasons for increasing of catalase activity in hypothyroidism.

The present study showed that administration of apelin per se or combination with $\mathrm{T} 4$ could improve the SOD, and GPx activity and TAC content after 14 days of treatment, while it could not affect the catalase activity.

To the best of knowledge, no other study has examined the effect of apelin alone or in combination with $\mathrm{T} 4$ on antioxidant capacity in hypothyroidism. There are a few studies about the role of apelin on antioxidant enzyme activity. In contrast to the finding of this study, a study reported that Catalase activity increased after 4 weeks of apelin administration in mice (Foussal et al. 2010). Moreover, Pisarenko et al. showed that apelin administration before ischemia in isolated heart increases the activity of SOD, catalase and glutathione peroxidase in the rat cardiac tissue (Pisarenko et al. 2014). Similar to our results, Zeng et al. illustrated that apelin increment the activity of SOD after inducing of hypoxia in rat cardiomyocytes (Zeng et al. 2009). It appears, in hypothyroidism, apelin therapy per se or accompanied by T4, had improved effect on SOD, GPx activity and TAC content. It appears, that apelin may prevent of the atherosclerosis formation in the heart tissue of hypothyroid rat by increment of antioxidant capacity and lowering the lipid peroxidation.

\section{CONCLUSION}

These findings suggest that apelin was able to improve the oxidant-antioxidant balance in the heart tissue of the hypothyroid rats and possibly is able to prevent cardiovascular damage induced by oxidative stress in those animals.

\section{ACKNOWLEDGMENTS}

The source of data used in this paper was from the Ph.D. thesis of Miss Farzaneh Faraji Shahrivar, a student of Ahvaz Jundishapur University of Medical Sciences. The authors gratefully acknowledge the help and financial support of the Physiology Research Center of Ahvaz Jundishapur University of Medical Sciences (grant No. APRC- 148). The authors express their gratitude to Laleh Hoghoghi, Hoda Ghadaksaz and Zahra Akhondali, for expert technical help.

\section{REFERENCES}

Aikawa R, Nagai T, Tanaka M, Zou Y, Ishihara T, Takano $\mathrm{H}$, et al. Reactive oxygen species in mechanical stress-induced cardiac hypertrophy. Biochem Bioph Res Co. 2001; 289: 901-907.

Araujo AS, Seibel FE, Oliveira UO, Fernandes T, Llesuy S, Kucharski L, et al. Thyroid hormoneinduced haemoglobin changes and antioxidant enzymes response in erythrocytes. Cell Biochem Funct. 2011; 29: 408-413.

Boucher J1 MB, Daviaud D, Gesta S, Guigné C, Mazzucotelli A, Castan-Laurell I, et al. Apelin, a Newly Identified Adipokine Up-Regulated by Insulin and Obesity. Endocrinology. 2005;146: 1764-1771. 
Cappola AR \& Ladenson PW. Hypothyroidism and atherosclerosis. J Clin Endocrinol Metab. 2003; 88: 2438-2444.

Chandrasekaran B, Dar O \& Mcdonagh T. The role of apelin in cardiovascular function and heart failure. Eur J Heart Fail. 2008;10: 725-732.

Coria MJ, Pastran AI \& Gimenez MS. Serum oxidative stress parameters of women with hypothyroidism. Acta Biomed. 2009: 80: 135-139.

Das K \& Chainy G. Modulation of liver mitochondrial antioxidant defense system by thyroid hormone. Biochem Biophys Acta. 2001; 1573: 1-13.

Dumitriu L, Bartoc R, Ursu H, Purice M \& Ionescu V. Significance of high levels of serum malonyl dialdehyde (MDA) and ceruloplasmin (CP) in hyper- and hypothyroidism. Endocrinologie. 1988; 26: 35-38.

Falcao-Pires I \& Leite-Moreira AF. Apelin: a novel neurohumoral modulator of the cardiovascular system. Pathophysiologic importance and potential use as a therapeutic target. Rev Port Cardiol. 2005; 24: 1263-1276.

Fazio S, Palmieri EA, Lombardi G, Biondi B,. Effects of thyroid hormone on the cardiovascular system. Recent Prog Horm Res. 2004; 59: 31-50.

Foussal C, Lairez O, Calise D, Pathak A, GuilbeauFrugier C, Valet P, et al,. Activation of catalase by apelin prevents oxidative stress-linked cardiac hypertrophy. FEBS Lett. 2010; 584: 2363-2370.

Grieve D J, Fletcher S, Pitsillides AA, Botham KM \& Elliott J. Effects of oral propylthiouracil treatment on nitric oxide production in rat aorta. $\mathrm{Br} J$ Pharmacol. 1999; 127: 1-8.

Halliwell B. Free radicals, antioxidants, and human disease: curiosity, cause, or consequence? Lancet 1994; 344: 721-724.

Hicks M, Wong LS \& Day RO. Antioxidant activity of propylthiouracil. Biochem Pharmacol. 1992; 43: 439-44.

Ichiki T. Thyroid hormone and atherosclerosis. Vascul Pharmacol . 2010; 52: 151-156.

Jahanbakhsh Z, Rasoulian B, Jafari M, Shekarforoush S, Esmailidehaj M, Mohammadi M T, et al. Protective effect of crocin against reperfusioninduced cardiac arrhythmias in anaesthetized rats. Excli J. 2012; 11: 20-29.

Japp AG, Cruden NL, Amer DA, Li VK, Goudie EB, Johnston NR, et al. Vascular effects of apelin in vivo in man. J Am Coll Cardiol. 2008, 52: 908-913.

Jashari F, Ibrahimi P, Nicoll R, Bajraktari G, Wester P, Henein MY. Coronary and carotid atherosclerosis: similarities and differences. Atherosclerosis. 2013; 227: 193-200.

Kawamata Y, Habata Y, Fukusumi S, Hosoya M, Fujii R, Hinuma S, et al. Molecular properties of apelin: tissue distribution and receptor binding. Biochim Biophys Acta. 2001;1538: 162-171.

Klein I, Danzi S. Thyroid disease and the heart. Circulation 2007;116: 1725-1735.

Lampka M, Junik R, Nowicka A, Kardymowicz H \& Kaczorowski P. Evaluation of low density lipoprotein oxidation in a course of hypothyroidism. Endokrynol Pol. 2006; 57: 116-121.

Messarah M, Boulakoud MS, Boumendjel A, Abdennour C \& El Feki A. The impact of thyroid activity variations on some oxidizing-stress parameters in rats. C R Biol. 2007; 330: 107-112.

Mishra P \& Samanta L. Oxidative stress and heart failure in altered thyroid States. Scientific World Journal. 2012; 741861, 2.

O'donnell VB, Chumley PH, Hogg N, Bloodsworth A, Darley-Usmar VM \& Freeman BA. Nitric oxide inhibition of lipid peroxidation: kinetics of reaction with lipid peroxyl radicals and comparison with alpha-tocopherol. Biochemistry. 1997; 36: 1521615223.

Pan T, Zhong M, Zhong X, Zhang Y \& Zhu D. Levothyroxine replacement therapy with vitamin $\mathrm{E}$ supplementation prevents oxidative stress and cognitive deficit in experimental hypothyroidism. Endocrine. 2013; 43: 434-439.

Pereira B, Rosa LF, Safi DA, Bechara EJ \& Curi R. Control of superoxide dismutase, catalase and glutathione peroxidase activities in rat lymphoid organs by thyroid hormones. J Endocrinol. 1994; 140: 73-77.

Pisarenko OI, Lankin VZ, Konovalova GG, Serebryakova LI, Shulzhenko VS, Timoshin AA, et al. Apelin-12 and its structural analog enhance antioxidant defense in experimental myocardial ischemia and reperfusion. Mol Cell Biochem. 2014; 391: 241-250.

Reddy VS, Gouroju S, Suchitra MM, Suresh V, Sachan A, Srinivasa Rao PV, et al. Antioxidant defense in overt and subclinical hypothyroidism. Horm Metab Res. 2013; 45: 754-8.

Sarandol E, Tas S, Dirican M \& Serdar Z. Oxidative stress and serum paraoxonase activity in experimental hypothyroidism: effect of vitamin $\mathrm{E}$ supplementation. Cell Biochem Funct. 2005; 23: 18.

Sarati L I, Martinez CR, Artes N, Arreche N, LopezCosta JJ, Balaszczuk AM, et al. Hypothyroidism: age-related influence on cardiovascular nitric oxide system in rats. Metabolism. 2012; 61: 1301-1311.

Sundaram V, Hanna AN, Koneru L, Newman HA \& Falko JM. Both hypothyroidism and hyperthyroidism enhance low density lipoprotein oxidation. J Clin Endocrinol Metab. 1997; 82: 34213424. 
Tatemoto K, Takayama K, Zou MX, Kumaki I, Zhang $\mathrm{W}$, Kumano $\mathrm{K}$, et al. The novel peptide apelin lowers blood pressure via a nitric oxide-dependent mechanism. Regul Pept. 2001; 99: 87-92.

Venditti P, Balestrieri M, Di Meo S \& De Leo T. Effect of thyroid state on lipid peroxidation, antioxidant defences, and susceptibility to oxidative stress in rat tissues. J Endocrinol. 1997; 155: 151157.

Von Eynatten M, Hamann A, Twardella D, Nawroth PP, Brenner H \& Rothenbacher D. Relationship of adiponectin with markers of systemic inflammation, atherogenic dyslipidemia, and heart failure in patients with coronary heart disease. Clin Chem. 2006; 52: 853-859.
Weetman AP, Tandon N \& Morgan BP. Antithyroid drugs and release of inflammatory mediators by complement-attacked thyroid cells. Lancet.1992; 340: 633-636.

Yilmaz S, Ozan S, Benzer F \& Canatan H. Oxidative damage and antioxidant enzyme activities in experimental hypothyroidism. Cell Biochem Funct. 2003; 21: 325-330.

Zeng XJ, Zhang LK, Wang HX, Lu LQ, Ma LQ \& Tang CS. Apelin protects heart against ischemia/reperfusion injury in rat. Peptides. 2009; 30: 1144-1152.

Received: June 03, 2015; Accepted: September 02, 2015. 